\title{
Ozone Water Is an Effective Disinfectant for SARS-CoV-2
}

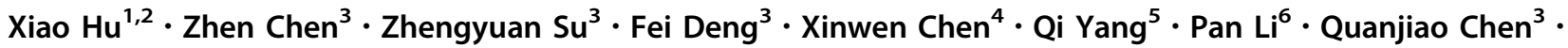

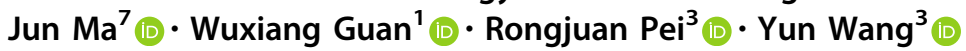

Received: 13 January 2021 / Accepted: 23 February 2021 / Published online: 31 March 2021

(c) Wuhan Institute of Virology, CAS 2021

Dear Editor,

The severe acute respiratory syndrome coronavirus 2 (SARS-CoV-2) is the causative pathogen of the pandemic coronavirus disease 2019 (COVID-19), which has infected nearly 90 million people and resulted in 2 million human deaths by the end of the year 2020. SARS-CoV-2 can survive in aerosols or on the surfaces of various materials for up to $72 \mathrm{~h}$ (Ong et al. 2020; van Doremalen et al. 2020). In China, although the human-to-human transmission pathway is under well control, the fomite transmission pathway now accounts for a significant fraction of new infection cases. Therefore, environmental disinfection of public areas and workspaces potentially contaminated by SARS-CoV-2 is an important measure to control the spread of COVID-19 by fomite transmission. A disinfectant that is safe and readily available at a low cost is urgently needed to meet environmental disinfection requirements.

Yun Wang

wangyun@wh.iov.cn

$\bowtie$ Rongjuan Pei

rongjuan_pei@wh.iov.cn

$\triangle$ Wuxiang Guan

guanwx@wh.iov.cn

$\triangle$ Jun Ma

majun@jit.edu.cn

1 CAS Key Laboratory of Special Pathogens and Biosafety, Wuhan Institute of Virology, Center for Biosafety Mega-Science, Chinese Academy of Sciences, Wuhan 430071, China

2 University of Chinese Academy of Sciences, Beijing 100049, China

3 State Key Laboratory of Virology, Wuhan Institute of Virology, Center for Biosafety Mega-Science, Chinese Academy of Sciences, Wuhan 430071, China

4 Guangzhou Institutes of Biomedicine and Health, Chinese Academy of Sciences, Guangzhou 510530, China

5 Department of Gastroenterology, Guangzhou Women and Children's Medical Center, Guangzhou 510623, China
Ozone is a highly reactive oxidant gas composed of three oxygen atoms and widely used in industry and medical waste disinfection (Elvis and Ekta 2011; Smithet al. 2017). A broad spectrum of viral pathogens (Sato et al. 1990), including SARS-CoV (Zhang et al. 2004), can be effectively inactivated by ozone treatment. The purpose of this study was to evaluate whether ozone water is a potential disinfectant to eliminate the environmental contamination of SARS-CoV-2.

The scheme of the experiment is showing in Fig. 1A. Briefly, $50 \mu \mathrm{L}$ viral supernatant was incubated with $225 \mu \mathrm{L}$ ozone water or unozonated tap water. After different incubation periods, the disinfection reaction was terminated by adding $225 \mu \mathrm{L}$ stopping buffer (complete culture media with $5 \mathrm{~g} / \mathrm{L}$ sodium thiosulfate). The resulting mixture was then inoculated into Vero E6 cells. At 24 and $48 \mathrm{~h}$ post-infection (hpi), the genomic RNA of secreted viruses was quantified by reverse transcription-polymerase chain reaction (qRT-PCR) assay using a Taqman probe targeting the $N$ gene of SARS-CoV-2 (Primers: 5'-TAACCAG AATGGAGAACGCAGTG- $3^{\prime} / 5^{\prime}$-TGAGTGAGAGCGGTG AACCAAGAC-3'; Probe:5'-ATCAAAACAACGTCGGCC CCAAGGT-3'/HEX + BHQ2) (Zheng et al. 2020). In parallel, the viral titers were determined by viral plaque assay at 96 hpi.

A recent report showed that the $\mathrm{Ct}$ values of SARSCoV-2 from various contaminated materials were generally between 25 to 32 (Ong et al. 2020). Based on this information and the observed correlation between $\mathrm{Ct}$ values and plaque-forming units (PFU) of SARS-CoV-2 (Uhteg et al. 2020), we estimated the viral PFU from common environmental contamination is approximately ranging from 0 to $10^{2} \mathrm{PFU} / \mathrm{mL}$. To check whether ozone water can inactivate environmental SARS-CoV-2 contamination, we

6 State Key Laboratory of Pollution Control and Resource Reuse, School of Environmental Science and Engineering, Tongji University, Shanghai 200092, China

7 State Key Laboratory of Urban Water Resource and Environment, School of Environment, Harbin Institute of Technology, Harbin 150090, China 
A
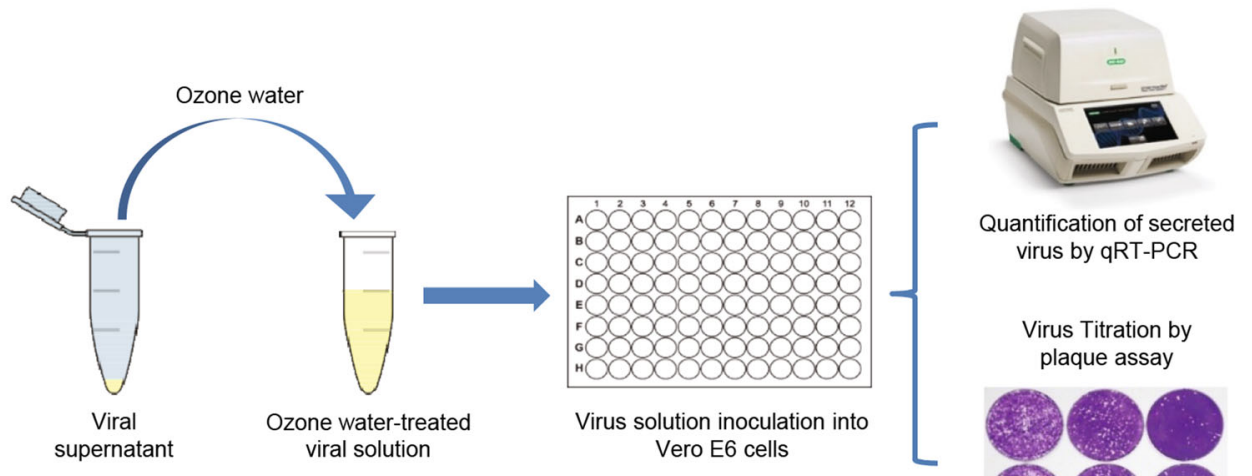
plaque assay

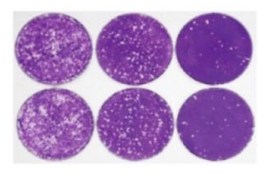

B

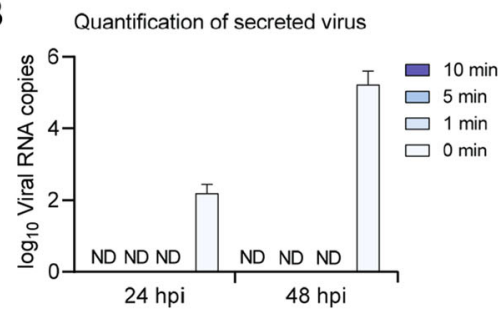

C

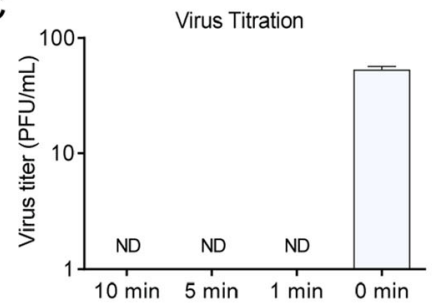

D

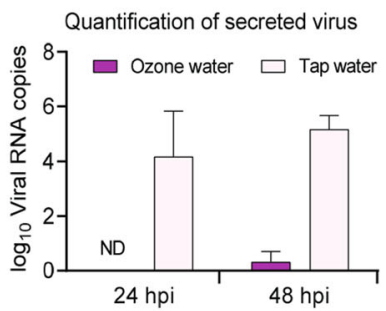

E

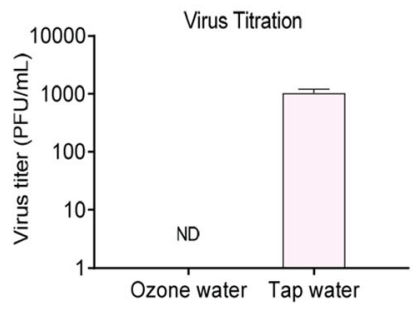

$\mathrm{F}$

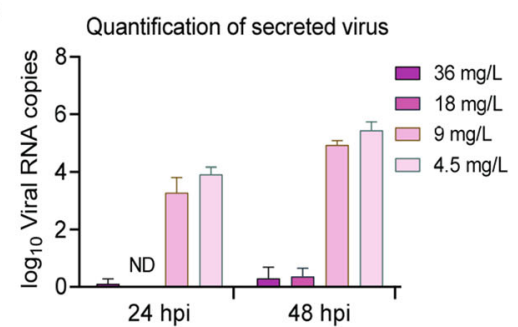

G

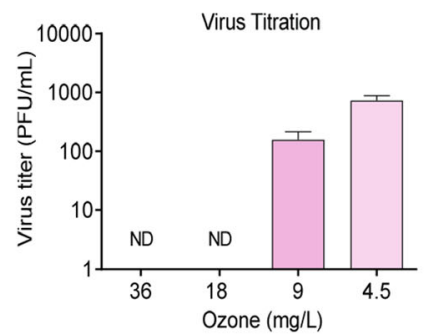

Fig. 1 Ozonated water inactivates SARS-CoV-2. A Scheme of the experiment. The viral supernatant was incubating with ozone water. After disinfection reaction, the mixture was then inoculated into Vero E6 cells. The secreted viruses in the supernatant were collected at $24 \mathrm{hpi}$ and $48 \mathrm{hpi}$, respectively, and subjected to qRT-PCR assay. The titers of viruses were determined by viral plaque assay at $96 \mathrm{hpi}$. B, C Contact time required for ozone water inactivation of SARS-CoV-2. Viral solution $\left(4.0 \times 10^{3} \mathrm{PFU} / \mathrm{mL}\right)$ was incubating with ozone water (36 mg/L) for $0,1,5,10 \mathrm{~min}$, respectively. The disinfection efficacy was evaluated by qRT-PCR (B) and viral plaque assay (C). D, E Disinfection capacity of ozone water. A higher PFU viral solution

diluted SARS-CoV-2 stock to $4.0 \times 10^{3} \mathrm{PFU} / \mathrm{mL}$, a 10-times higher PFU than the estimated upper limit of environmental virus contamination. The viral solution was incubated with ozone water ( $36 \mathrm{mg} / \mathrm{L}$ ozone) for $0,1,5$, or $10 \mathrm{~min}$, respectively. No viral genomic RNA or viral plaques were detected after ozone water treatment for $1 \mathrm{~min}$ (Fig. 1B, 1C), suggesting that ozone water could effectively inactivate SARS-CoV-2 in less than $1 \mathrm{~min}$. When viral PFU increased to $4.0 \times 10^{4} \mathrm{PFU} / \mathrm{mL}$, ozone water (36 mg/L ozone) could still fully inactivate $50 \mu \mathrm{L}$ viral solution in less than $1 \mathrm{~min}$ compared to tap water-treatment (Fig. 1D, 1E). $\left(4.0 \times 10^{4} \mathrm{PFU} / \mathrm{mL}\right)$ was incubated with ozone water $(36 \mathrm{mg} / \mathrm{L}$ ozone $)$ or tap water $(0 \mathrm{mg} / \mathrm{L}$ ozone $)$, respectively. Similar tests were performed to quantify viral RNA and titers by qRT-PCR $(\mathbf{D})$ and plaque assay $(\mathbf{E})$. F, G Ozone concentration required for ozone water inactivation of SARS-CoV-2. Serially diluted ozone water $(36,18,9,4.5 \mathrm{mg} / \mathrm{L})$ was incubating with the viral solution $\left(4.0 \times 10^{4} \mathrm{PFU} / \mathrm{mL}\right)$ for $1 \mathrm{~min}$, and the disinfection efficacy was determined by qRT-PCR (F) and viral plaque assay $(\mathbf{G})$, as mentioned above. The data points indicated the averages of triplicate experiments, and the error bars represent the standard error of the mean (SEM). ND: not detected.

To further determine the minimal ozone water concentration required to inactivate SARS-CoV-2, ozone water was serially diluted and incubated with the viral solution $\left(4.0 \times 10^{4} \mathrm{PFU} / \mathrm{mL}\right)$ for $1 \mathrm{~min}$ to inactivate the virus. We found that SARS-CoV-2 was fully inactivated by ozone water harboring $36 \mathrm{mg} / \mathrm{L}$ and $18 \mathrm{mg} / \mathrm{L}$ ozone, as neither viral genomic RNA nor viral plaques were detected (Fig. 1F, 1G). However, when ozone concentration was below $9 \mathrm{mg} / \mathrm{L}$ in ozone water, the genomic RNA copy number of SARS-CoV-2 was detected in the range of $4.0 \times 10^{3}$ and $5.0 \times 10^{5}$ copies $/ \mathrm{mL}$ (Fig. $1 \mathrm{~F}$ ), and the virus titer was between $1.0 \times 10^{2}$ and $7.0 \times 10^{2} \mathrm{PFU} / \mathrm{mL}$ 
(Fig. 1G). The above results implied that ozone concentration above $18 \mathrm{mg} / \mathrm{L}$ could effectively eliminate SARSCoV-2 infectivity within 1 min.

In summary, we demonstrated that ozone water is an effective disinfectant in the elimination of SARS-CoV-2. Compared to the traditional chemical disinfectant, ozone water offers several advantages. Firstly, ozone water is eco-friendly and will not cause a secondary hazard to the environment after its administration. The residual ozone in the water can be decomposed rapidly and converted to oxygen within a short period (typically within $30 \mathrm{~min}$ ) under natural conditions. This feature is highly valuable for food disinfection. Secondly, an ozone water generator's price is usually as low as 8,000 Yuan in China, which can convert tons of tap water into ozone water in less than $30 \mathrm{~min}$. Such ease of production at a low cost makes ozone water far superior to traditional chemical disinfectants, particularly when a large amount of disinfectant is needed to disinfect a large area, e.g., a cold warehouse for imported food, which is usually contaminated with SARSCoV-2. In contrast, traditional disinfectants like ethanol, the price is usually over 10,000 Yuan per ton in China. Thirdly, SARS-CoV-2 can be inactivated by ozone water within $1 \mathrm{~min}$, which is very efficient. In addition to ozone water, other studies also showed that ozone gas is highly effective in eliminating SARS-CoV-2 (Criscuolo et al. 2021). In our opinion, ozone gas has a considerable advantage in disinfecting virus contamination in the aerosol, whereas ozone water is more effective in surface disinfection simply by immersing contaminated material in the ozone water. However, both forms of ozone must be administrated with caution to prevent lung injury due to the inhalation of ozone gas.

Although further study is needed to evaluate the disinfection efficacy of ozone water in real-world conditions, our study provides the first step in the proof of principle before applying ozone water in environmental settings.

Acknowledgements This work was supported by National Key Research and Development Program (2020YFC0846200). We acknowledge Mr. Hao Tang and Mr. Jun Liu for their assistance in BSL-3 laboratory work.

\section{Compliance with Ethical Standards}

Conflict of interest The authors declare that they have no conflict of interest.

Animal and Human Rights Statement This article does not contain any studies with human or animal subjects performed by any of the authors.

\section{References}

Criscuolo E, Diotti RA, Ferrarese R, Alippi C, Viscardi G, Signorelli C, Mancini N, Clementi M, Clementi N (2021) Fast inactivation of SARS-CoV-2 by UV-C and ozone exposure on different materials. Emerg Microbes Infect 10:206-210

Elvis AM, Ekta JS (2011) Ozone therapy: a clinical review. J Nat Sci Biol Med 2:66-70

Ong SWX, Tan YK, Chia PY, Lee TH, Ng OT, Wong MSY, Marimuthu K (2020) Air, surface environmental, and personal protective equipment contamination by severe acute respiratory syndrome coronavirus 2 (SARS-CoV-2) from a symptomatic patient. JAMA 323:1610-1612

Sato H, Wananabe Y, Miyata H (1990) Virucidal effect of ozone treatment of laboratory animal viruses. Jikken Dobutsu 39:223-229

Smith NL, Wilson AL, Gandhi J, Vatsia S, Khan SA (2017) Ozone therapy: an overview of pharmacodynamics, current research, and clinical utility. Med Gas Res 7:212-219

Uhteg K, Jarrett J, Richards M, Howard C, Morehead E, Geahr M, Gluck L, Hanlon A, Ellis B, Kaur H, Simner P, Carroll KC, Mostafa HH (2020) Comparing the analytical performance of three SARS-CoV-2 molecular diagnostic assays. J Clin Virol 127:104384

van Doremalen N, Bushmaker T, Morris DH, Holbrook MG, Gamble A, Williamson BN, Tamin A, Harcourt JL, Thornburg NJ, Gerber SI, Lloyd-Smith JO, de Wit E, Munster VJ (2020) Aerosol and Surface Stability of SARS-CoV-2 as compared with SARS-CoV-1. N Engl J Med 382:1564-1567

Zhang JM, Zheng CY, Xiao GF, Zhou YQ, Gao R (2004) Examination of the efficacy of ozone solution disinfectant in in-activating SARS virus. Chin J Disinfect 21:27-28 (in Chinese)

Zheng X, Wang H, Su Z, Li W, Yang D, Deng F, Chen J (2020) Coinfection of SARS-CoV-2 and Influenza virus in Early Stage of the COVID-19 Epidemic in Wuhan, China. J Infect 81:e128 e129 